\title{
A preliminary study on quantification of biological nitrogen fixation in sugarcane grown in Sevanagala in Sri Lanka
}

\author{
N.S. Abeysingha ${ }^{1^{*}}$ and C.S.Weerarathne ${ }^{2}$ \\ ${ }^{1}$ Department of Soils and Water Resources Management, Faculty of Agriculture, Rajarata University of Sri Lanka, Puliyankulama, Anuradhapura. \\ ${ }^{2}$ Pelwatte Sugar Industries Company, Melbourne Avenue, Colombo 04.
}

Revised: 08 January 2010 ; Accepted: 23 February 2010

\begin{abstract}
The extent of nitrogen(N) fixation in sugarcane grown in reddish brown earth soils in Sevanagala was determined using the difference in ${ }^{15} \mathrm{~N}$ abundance in the top visible dewlap leaves of sugarcane (variety CO 775, SL 8306) compared to those of neighbouring weeds. Results indicate that biological $\mathrm{N}_{2}$ fixation contributed to an average of $18 \%$ of the total $\mathrm{N}$ in sugarcane in the study site.
\end{abstract}

Keywords: Biological nitrogen fixation, ${ }^{15} \mathrm{~N}$ natural abundance technique, sugarcane.

\section{INTRODUCTION}

Nitrogen $(\mathrm{N})$ is one of the important plant nutrients necessary for sugarcane production. Over the next few decades, due to depletion of petroleum reserves and increased production costs of other fuels, price rise of inorganic nitrogenous fertilizers may be inevitable. Hence it becomes imperative to substitute inorganic nitrogen by a cheap source which can at least partially meet the crop requirements.

If $\mathrm{N}_{2}$ fixing bacteria inhabit the rhizosphere of any plant or occur endophytically in the plant tissues, it would be a symbiotic association similar to that found in legumes and rhizobia. It has been found in Brazil and few other countries where sugarcane is grown, that endophytic nitrogen fixing bacteria associated with some sugarcane varieties supply a considerable amount of nitrogen. A variety of $\mathrm{N}_{2}$-fixing (diazotrophic) bacteria (Beijerinckia, Bacillus, Klebsiella, Enterobacter, Erwinia, Azospirillum, Herbaspirillum and Gluconaacetobacter) have been isolated from the rhizosphere, roots, stems, and leaves of sugarcane ${ }^{1,2}$.
Some sugarcane varieties grown in Brazil obtain over $60 \%$ of total plant $\mathrm{N}$ (equivalent to over $200 \mathrm{~kg} \mathrm{~N} / \mathrm{ha} /$ year) from biological nitrogen fixation $(\mathrm{BNF})^{2}$. Further, sugarcane varieties CB 45-3 and SP 70-1143 were found to fix $170-210 \mathrm{~kg} \mathrm{~N} /$ ha/year when grown with ample phosphorus(P) and foliar application of molybdenum (Mo) $(500 \mathrm{~g} / \mathrm{ha})$ and these varieties have given $180 \mathrm{t} / \mathrm{ha}$ even when grown in very low fertile soils without any nitrogen fertilization. A previous study ${ }^{3}$ estimated that average $\mathrm{N}$ input to sugarcane plant by BNF was $28 \%$ to $33 \%$ of the total $\mathrm{N}$ in the plant when grown in a research field in central Thailand. Sugarcane grown in some sites in Brazil, Philippines and Miyako Island in Japan was found to fix $33 \%$ of $\mathrm{N}$ by $\mathrm{BNF}^{4}$.

The ${ }^{15} \mathrm{~N}$ natural abundance technique appears to provide a better quantitative measure of BNF associated with legume or actinorhizal tree species in natural ecosystems, plantations or agro forestry systems over the various other methods such as total $\mathrm{N}$ difference method, acetylene reduction assay, and other ${ }^{15} \mathrm{~N}$ methodologies ${ }^{5}$. As a result of isotope discrimination effects that occur during soil formation, most soils have slightly higher ${ }^{15} \mathrm{~N}$ abundance than the atmosphere. Because of this difference, nitrogen fixing plants have been found to have a lower ${ }^{15} \mathrm{~N}$ enrichment than non fixing ones and this has been the basis for the ${ }^{15} \mathrm{~N}$ natural abundance technique. With the development of automated high precision continuous flow isotope ratio mass spectrometers, the use of ${ }^{15} \mathrm{~N}$ natural abundance version of the isotope ratio has become a more accurate technique ${ }^{5,6}$. The application of this technology to estimate BNF associated with sugarcane has been thoroughly discussed ${ }^{6}$.

${ }^{*}$ Corresponding author (nimalabeysingha@yahoo.com) 
Sugarcane is grown in Sri Lanka with low $\mathrm{N}$ fertilizers compared to other countries, yet it gives a substantial yield. In addition, some $\mathrm{N}$ fertilizer trials and NPK fertilizer trials conducted in Sri Lanka show no significant results in both cane and sugar yield ${ }^{7}$. This may be attributed to the presence of BNF in Sri Lankan sugarcane varieties. Therefore, this study was undertaken to quantify the extent of BNF associated with sugarcane cultivated in the Sevanagala sugarcane plantation in Sri Lanka.

\section{METHODS AND MATERIALS}

Ginigalpallassa area of the Sevanagala sugarcane plantation was selected for this study. According to a previous study ${ }^{6},{ }^{15} \mathrm{~N}$ natural abundance technique was used to quantify the BNF in sugarcane. Allotments of 13 farmers, which were closely located, were selected by considering the age $(7-8$ months after planting or ratooning), type of the crop (plant or ratoon), and the variety of the crop. Soils of all these allotments were reddish brown earth (Rhodustalf). In each allotment, 15 Top Visible Dewlap (TVD) cane leaf samples were randomly collected and bulked by allotments separately. Simultaneously, 2-3 types of weed samples (non leguminous) in each allotment were collected, and the whole shoots of weeds were bulked by botanical species, separately for each allotment. Bulked samples were dried at $65{ }^{\circ} \mathrm{C}$ for about $72 \mathrm{~h}$ and ground using a mill to a fine powder. ${ }^{15} \mathrm{~N}$ abundance of these samples was determined using continuous flow isotope ratio mass spectrometry. These samples were analyzed for ${ }^{15} \mathrm{~N}$ by the International Atomic Energy Authority (IAEA) in Austria. The \% $\mathrm{N}_{2}$ derived from $\mathrm{N}$ fixation ( $\% \mathrm{Ndfa}$ ) was calculated for each allotment as follows ${ }^{4}$.
$\% \mathrm{Ndfa}=\left(1-\delta^{15} \mathrm{~N}\right.$ value of sugarcane $/ \delta^{15} \mathrm{~N}$ value of neighbouring plants) $\mathrm{X} 100$

In this estimation, isotopic fractionation during $\mathrm{N}$ fixation by associated bacteria was assumed to be zero. When the reference plants (weeds) had ${ }^{15} \mathrm{~N}$ value lower than sugarcane, $\% \mathrm{Ndfa}$ was assumed to be zero ${ }^{4}$. An average value of $\% \mathrm{Ndfa}$ was obtained for Ginigalpallasse area of the Sevanagala plantation.

\section{RESULTS}

The $\mathrm{N}$ content, ${ }^{15} \mathrm{~N}$ abundance $\left[\delta{ }^{15} \mathrm{~N}(\%)\right]$ and the $\% \mathrm{~N}$ derived from $\mathrm{N}_{2}$ fixation (\% Ndfa) of plant crops of each cane allotment are shown in Table 1 and the above values for the ratoon crops are shown in Table 2. As a whole, the $\delta{ }^{15} \mathrm{~N}(\%)$ value of sugarcane was lower than those of neighbouring weeds in seven allotments. BNF appears to have not taken place in sugarcane grown in allotments C-07-29, C-07-51, D-02-330 and D-02-324 while cane in other allotments have fixed $\mathrm{N}_{2}$ as shown in Tables 1 and 2 . The $\delta{ }^{15} \mathrm{~N}(\%)$ value of sugarcane and neighbouring weeds showed too much variation. The possible average contribution of $\mathrm{N}_{2}$ fixation to total $\mathrm{N}$ in sugarcane was about $18 \%$ within a range of $0-77 \%$ concerning both plant and ratoon crop. However, in this study ratoon cane has shown higher average BNF ability $(22.3 \%)$ than the plant crop (8\%).

\section{DISCUSSION AND CONCLUSION}

These results show that a considerable level of nitrogen fixation occurs in the study site though the variation is too large. If the number of sample sites was increased,

Table 1: ${ }^{15} \mathrm{~N}$ natural abundance, $\% \mathrm{~N}$ of TVD leaves and weeds, $\% \mathrm{~N}$ derived from $\mathrm{N}_{2}$ fixation of plant crops

\begin{tabular}{|c|c|c|c|c|c|c|}
\hline Location & Cane variety & Growth cycle & Reference plant & $\delta{ }^{15} \mathrm{~N}(\% 0)$ & $\% \mathrm{Ndfa}$ & $\% \mathrm{~N}$ \\
\hline \multirow[t]{4}{*}{ C-07-51 } & CO 775 & Plant crop & & 7.58 & & 1.44 \\
\hline & & & Borreria hispida & 2.60 & 0 & 2.74 \\
\hline & & & Euphorbia hirta & 2.62 & 0 & 2.34 \\
\hline & & & Crassocephalum crepidioides & 4.21 & 0 & 2.91 \\
\hline \multirow[t]{3}{*}{ C-06- 46} & CO 775 & Plant crop & & 3.65 & & 1.31 \\
\hline & & & Borreria latifolia & 2.82 & 0 & 1.99 \\
\hline & & & Ageratum conyzoides & 4.10 & 11 & 2.93 \\
\hline \multirow[t]{3}{*}{ C-03-09 } & CO 775 & Plant crop & & 4.62 & & 1.57 \\
\hline & & & Echinochloa colonum & 9.28 & 51 & 1.55 \\
\hline & & & Euphorbia hirta & 5.09 & 10 & 1.21 \\
\hline \multirow[t]{3}{*}{ D-02-330 } & CO 775 & Plant crop & & 7.28 & & 1.63 \\
\hline & & & Scoporia oauls & 7.15 & 0 & 2.31 \\
\hline & & & Solanum nigrum & 5.76 & 0 & 3.11 \\
\hline
\end{tabular}


variation would be less. In a similar study conducted in several areas in the Philippines and three sites in Miyako Island (Japan), it has been found that BNF contributed to an average of $33 \%$ within a range of $0-72 \%{ }^{4}$. Moreover, another study ${ }^{6}$ using a similar technique found that $60 \%$ of plant $\mathrm{N}$ in sugarcane in a commercial plantation was derived from BNF. In addition, Shotaro et al. ${ }^{3}$ have estimated BNF in sugarcane cultivated in central Thailand to be $28-33 \%$ using cassava as reference plants.

A previous study ${ }^{6}$ pointed out that optimum fertilization with $\mathrm{P}$, potassium $(\mathrm{K})$ and micronutrients and year-round irrigation are important to occur high BNF in sugarcane. In the present study, only NPK fertilizers were used and year-round irrigation was not practised.

Due to limited facilities, only a limited number of samples were analyzed for $\delta^{15} \mathrm{~N}$ values. Weed samples were not replicated and hence, it was not possible to estimate the statistical significance of BNF for each variety and for each allotment. However, the average BNF value estimated from this study for this area is accurate and it is a considerable quantity in terms of $\mathrm{N}$ fertilizer.

Table 2: ${ }^{15} \mathrm{~N}$ natural abundance, $\% \mathrm{~N}$ of $\mathrm{TVD}$ leaves and weeds, $\% \mathrm{~N}$ derived from $\mathrm{N}$ fixation

\begin{tabular}{|c|c|c|c|c|c|c|}
\hline Location & Cane variety & Growth cycle & Reference plant & $\delta{ }^{15} \mathrm{~N}(\% 0)$ & $\% \mathrm{Ndfa}$ & $\% \mathrm{~N}$ \\
\hline \multirow[t]{4}{*}{ C-06-288 } & $\mathrm{CO} 775$ & $2^{\text {nd }}$ ratoon & & 1.66 & & 1.24 \\
\hline & & & Eleutheranthera ruderalis & 2.96 & 44 & 1.87 \\
\hline & & & Corchorus aestuans & 2.80 & 41 & 2.16 \\
\hline & & & Scoporia oauls & 7.43 & 77 & 1.86 \\
\hline \multirow[t]{4}{*}{ C-07-29 } & SL 8306 & $1^{\text {st }}$ ratoon & & 5.90 & & 1.46 \\
\hline & & & Aeschynomene indika & -0.52 & 0 & 4.10 \\
\hline & & & Mitracarpus hirtus & 2.39 & 0 & 2.92 \\
\hline & & & Varnonia cinerea & 1.91 & 0 & 2.63 \\
\hline \multirow[t]{4}{*}{ C-05-126 } & $\mathrm{CO} 775$ & $6^{\text {th }}$ ratoon & & 3.96 & & 1.45 \\
\hline & & & Digitaria ischaemum & 3.84 & 0 & 1.59 \\
\hline & & & Unknown & 7.2 & 45 & 1.58 \\
\hline & & & Commelina benghalensis & 4.59 & 14 & 3.04 \\
\hline \multirow[t]{3}{*}{ C-06-129 } & $\mathrm{CO} 775$ & $6^{\text {th }}$ ratoon & & 2.48 & & 1.22 \\
\hline & & & Corchorus aestuans & 5.06 & 51 & 2.54 \\
\hline & & & Ageratum conyzoides & 3.26 & 24 & 2.93 \\
\hline \multirow[t]{3}{*}{ D-02-547 } & SL 8306 & $3^{\text {rd }}$ ratoon & & 4.73 & & 1.68 \\
\hline & & & Amaranthus viridis & 5.45 & 14 & 3.82 \\
\hline & & & Cleome viscosa & 5.46 & 13 & 3.94 \\
\hline \multirow[t]{4}{*}{ D-02-535 } & SL 8306 & $1^{\text {st }}$ ratoon & & 4.50 & & 1.45 \\
\hline & & & Atylosia scara baeoides & 1.50 & 0 & 2.10 \\
\hline & & & Cucumis callosus & 4.64 & 4 & 2.66 \\
\hline & & & Hibiscus lobatus & 3.47 & 0 & 2.43 \\
\hline \multirow[t]{4}{*}{ D-02-324 } & $\mathrm{CO} 775$ & $15^{\text {th }}$ ratoon & & 3.71 & & 1.80 \\
\hline & & & Tridex procubens & 2.80 & 0 & 2.02 \\
\hline & & & Ipomoea pestigridis & 2.66 & 0 & 2.40 \\
\hline & & & Phaseolus lathyroides & -1.12 & 0 & 3.39 \\
\hline \multirow[t]{3}{*}{ D-04- 1563} & $\mathrm{CO} 775$ & $3^{\text {rd }}$ ratoon & & 3.09 & & 1.39 \\
\hline & & & Scoporia oauls & 7.43 & 58 & 1.86 \\
\hline & & & Solanum nigrum & 5.76 & 46 & 3.11 \\
\hline \multirow[t]{3}{*}{ D-04-138 } & $\mathrm{CO} 775$ & $1^{\text {st }}$ ratoon & & 3.55 & & 1.45 \\
\hline & & & Phylanthus niruri & 5.76 & 38 & 3.12 \\
\hline & & & Mikania scandense & 6.31 & 44 & 1.97 \\
\hline
\end{tabular}


Application of ${ }^{15} \mathrm{~N}$ natural abundance technique and other independent techniques to quantify BNF have been discussed thoroughly in a previous study ${ }^{5}$. According to this study, ${ }^{15} \mathrm{~N}$ natural abundance technique is the best tool to quantify the BNF in an agro-ecosystem. It has been recommended to use a number of different, preferably botanically diverse reference plants; however two - three non nitrogen reference plants have also been accepted to quantify the BNF associated with sugarcane ${ }^{6}$. Similarly, two - three reference plants were used in this study. Since BNF potential of sugarcane depends on genotype, it is suggested to investigate the BNF potential of all commercial sugarcane varieties in the country. This preliminary study examines whether sugarcane grown in Sri Lanka has the ability to fix $\mathrm{N}_{2}$ from atmosphere. As the study was carried out only in Sevanagala, it is important to quantify the extent of BNF associated with sugarcane cultivated in other sugarcane growing areas of the country.

In almost all countries in the world where sugarcane is grown, BNF ability of sugarcane is used for sustainable sugarcane production. The findings reported in the present study can be used to improve the $\mathrm{N}$ fertilizer recommendation for sugarcane production, to select varieties for breeding programmes and to isolate diazotrophic bacteria for the production of bio fertilizer. Some N fertilizer trials conducted in certain areas of this plantation had not shown any significant difference in the yield ${ }^{7}$ (even in 1:2:3 N in the trial). Based on the results of this study, this non significant response may be attributed to the presence of BNF associated with sugarcane in the area.

Several attempts to isolate nitrogen fixing bacteria from sugarcane showed Gluconoacetobacter diazotrophicus as the most common species ${ }^{8}$. This species is able to fix nitrogen in a medium of high sugar concentration, low $\mathrm{pH}$ and in the presence of nitrate. Gluconoacetobacter diazotrophicus has been found in all parts of the sugarcane plant including post harvest residues remaining in the fields 9 . Inoculation methods of biological nitrogen fixing bacteria have also been investigated. In addition, it is widely accepted that some biological nitrogen fixing bacteria produce plant growth promoters such as auxins, gibberellins and cytokinins ${ }^{10}$.

The findings of this preliminary study indicate the presence of BNF in sugarcane under Sri Lankan conditions. It is therefore necessary to conduct detailed studies to utilize BNF in sugarcane growing areas of Sri Lanka.

\section{Acknowledgement}

The authors acknowledge the IAEA for the analysis of samples and also the Atomic Energy Authority of Sri Lanka for supporting to send samples to IAEA. The authors thank the staff of the Chemistry Division and the Director of Sugarcane Research Institute (SRI), UdaWalawe for their cooperation and also Dr. W.G. Witharama, Agronomist, SRI for the support in identifying weeds.

\section{References}

1. Perchase B.S. (1980). Nitrogen fixation associated with sugarcane. Proceedings of the South African Sugar Technologists' Association June: 173-176.

2. Boddey R.M., Urquiaga S., Reis V. \& Dobereiner J. (1991). Biological nitrogen fixation with sugarcane. Plant and Soil 137(1): 111-117.

3. Ando S., Meunchang S., Thippayarugs S., Prasertsak P., Matsumoto N. \& Yoneyama T. (2004). Role of nitrogen fixation for sustainable sugarcane production. Proceedings of the International Symposium on Sustainable Sugarcane and Sugar Production Technology, Nanning, China, 29 November -2 December, 2004, 156 -159.

4. Yoneyama T., Muraoka T., Kim T.H., Dacanay E.V. \& Nakanishi Y. (1997). The natural ${ }^{15} \mathrm{~N}$ abundance of sugarcane and neighboring plants in Brazil, the Philippines and Miyako(Japan). Plant and Soil 189(2): 239-244.

5. Boddey R.M., Peoples M.B., Palmer B. \& Dart P.J. (2000). Use of the ${ }^{15} \mathrm{~N}$ natural abundance technique to quantify biological nitrogen fixation by woody perennials. Nutrient Cycling in Agro Ecosystems 57(3): 235-270.

6. Boddey R.M., Polidoro J.C., Alexander S.R., Bruno J.R.A. \& Urquiaga S. (2001). Use of the ${ }^{15} \mathrm{~N}$ natural abundance technique for the quantification of the contribution of $\mathrm{N}_{2}$ fixation to sugarcane and other grasses. Australian Journal of Plant Physiology 28(9): 889-895.

7. Sugarcane Research Institute of Sri Lanka (2000, 2005 and 2006). Annual Reports. Sugarcane Research Institute of Sri Lanka, Uda Walawe.

8. Ovidio P., Ovalle W. \& Urquiaga S. (2005). Update on biological nitrogen fixation research on sugarcane in Guatemala. Proceedings of the International Society of Sugercane Technologists 25: 105-109.

9. Fuentes L.E., Jimenez-salgado T., Abarca I.R. \& Mellado J.C. (1993). Acetobacter diazotrophicus, an indoleacetic acid prodcing bacterium isolated from sugarcane cultivars of Mexico. Plant and Soil 154(2): 145-150.

10. Moutia J.F.Y., Umrit G., Saumtally A.S. \& Ngkee kwong K.F. (2005). Occurrence of diazotrophic and growth promoting rhizobacteria associated with sugarcane in Mauritius. Proceedings of the International Society of Sugercane Technologyists 25: 111 -116. 